\title{
Predicting Rainfall Erosivity In Honduras
}

\author{
by \\ E.A. Hikhailova \\ R.B. Bryant \\ S.J. Schwager \\ and \\ S.D. Smith
}

BU-1353-M

June 1996 


\section{PREDICTING RAINFALL EROSIVITY IN HONDURAS}

E.A. Mikhailoval*, R.B. Bryant ${ }^{1}$, S.J. Schwager ${ }^{2}$, and S.D. Smith ${ }^{3}$

${ }^{1 *}$ E.A. Mikhailova and ${ }^{1}$ R.B. Bryant, Cornell Univ., Dept. of Soil, Crop and Atmospheric Sciences, Bradfield Hall, Ithaca, NY 14853; 2S.J. Schwager, Cornell Univ., Biometrics Unit and Statistics Center, Warren Hall, Ithaca, NY 14853; 3S.D. Smith, Cornell Univ., Cornell Laboratory for Environmental Applications of Remote Sensing (CLEARS), Emerson Hall, Ithaca, NY 14853. Contribution from the Cornell Univ. Agricultural Experiment Station, Cornell Univ., Ithaca, NY 14853. ${ }^{*}$ Corresponding author (emloecornell.edu).

\section{ACKNOWLEDGMENTS}

We wish to acknowledge Escuela Agrícola Panamericana (EAP) in Zamorano, Empresa Nacional de Energía Electrica de Honduras (ENEE), Departamento de Servicios Hidrologicos y Climatologicos de Honduras (DSHC), Servicio Meteorologico Nacional de Honduras (SMN), Servicio Nacional de Acueductos y Alcantarillas (SANAA) for providing assistance and access to all relevant information. This research was supported by the Cornell International Institute for Food, 
1 Agriculture and Development (CIIFAD) and the Cornell

2 University Agricultural Experiment Station. Technical

3 support was provided by the Cornell Laboratory for

4 Environmental Applications of Remote Sensing (CLEARS) - 


\section{PPEDICTING RAINFALL EROSIVITY IN HONDURAS}

\section{ABSTRACT}

The rainfall erosivity index ( $R$ ) from the Universal Soil Loss Equation (USLE) (Wischmeier and Smith, 1965; 1978) and its modern version, the Revised Universal Soil Loss Equation (RUSLE) (Renard et al., 1991; Renard et al., 1994), was utilized to evaluate rainfall erosivity in Honduras. In addition to average annual precipitation, elevation was highly significant in predicting the rainfall erosivity. Analyses of data sets from Costa Rica, Sri Lanka, and the southeastern United States showed similar patterns. Using previously calculated R-factor values for eight climatic stations in Honduras, a regression relationship was established for estimating the rainfall erosivity index as a function of average annual precipitation and elevation. This regression model was used to estimate the rainfall erosivity index for each of the 352 Honduran climatic stations without calculated Rfactor values. A provisional iso-erodent map of Honduras at a scale 1:1,000,000 was compiled, using a basemap obtained from the Digital Chart of the World (Environmental Systems Research Institute, Inc, 1993). The iso-erodent map displays ranges of the R-factor values and iso-lines 
representing $95 \%$ prediction intervals for new R-factor estimates.

\section{INTRODUCTION}

Climatic erosivity is defined (Lal, 1990) as the aggressiveness of the climate (rain, wind, snow) toward erosion. The rainfall erosivity factor ( $R$ ), or $R$-factor, in the USLE/RUSLE model (Wischmeier and Smith, 1965, 1978; Renard et al., 1994) is an index of rainfall erosivity, which allows prediction of the potential erosive power of the rainfall. The methods used to calculate the $\mathrm{R}$-factor are described by Wischmeier and Smith (1978) and in the RUSLE user guide (Renard et al., 1994).

The rainfall erosivity factor was the focus of this study because it can provide useful information independent of the USLE/RUSLE model. Iso-erodent maps produced on the basis of this factor can be used to identify regions with high rainfall erosive potential. The R-factor values can be readily calculated for locations where hourly rainfall intensities are known (Wischmeier and Smith, 1978). However, calculation of the R-factor values for new locations is laborious and requires long-term rainfall intensity data. Such information for Honduras was limited. Alternatively, rainfall erosivity has been estimated from average annual precipitation data (Renard and Freimund, 
1994 ). Bollinne et al. (1980) developed a provisional isoerodent map for Belgium; precipitation was utilized to estimate $\mathrm{R}$ by simple linear regression using three observations. An iso-erodent map of India (Babu et al., 1978) was based on average annual and seasonal precipitation for 44 climatic stations. The objectives of the study reported here were to collect from numerous sources the basic climatic data for weather stations in Honduras, to use this information to estimate $\mathrm{R}$-factor values, and to produce an iso-erodent map for the country. The estimation of R-factor values is based on the use of both elevation and average annual precipitation as regressors. This procedure improves substantially over the use of precipitation data only, which is the approach of previous work on this topic.

\section{MATERIALS AND METHODS}

Previously existing calculated erosivity indices for eight climatic stations in the El Cajon watershed and the mean annual precipitation and elevation of these stations are presented in Table 1. Each erosivity index is an average value over a 15 to 16 year period. The rainfall energy per unit depth of rainfall $\left(e_{r}\right)$, a component used in calculating the R-factor value, was estimated using the relation (Foster et al., 1981) 
1

9

$$
\begin{array}{ll}
e_{x}=0.119+0.0873 \log _{10}\left(i_{x}\right) & i_{x} \leq 76 \mathrm{~mm} \mathrm{~h}^{-1} \\
e_{x}=0.283 & i_{x}>76 \mathrm{~mm} \mathrm{~h}
\end{array}
$$

where

$\mathbf{e}_{\mathbf{r}} \quad=$ kinetic energy in megajoules per hectare per millimeter of rainfall ( $M J \mathrm{ha}^{-1} \mathrm{~mm}^{-1}$ );

$i_{x} \quad=$ intensity of rainfall $\left(\mathrm{mm} \mathrm{h}^{-1}\right)$.

A modification of the general procedure for developing a rainfall erosivity map as discussed by Renard and Freimund (1994) was used in this study; it is outlined in the following steps:

1) Calculated R-factor values for climatic stations were obtained wherever possible from existing studies;

2) A linear regression relationship was developed between the calculated $\mathrm{R}$-factor values and the average annual precipitation and elevation values for these climatic stations;

3) The developed relationship was used to estimate $\mathrm{R}$-factor values for other climatic stations without calculated $R$-factor values;

4) Estimated and calculated R-factor values were plotted on a map, and iso-lines (iso- 
erodents) were drawn connecting points with equal R-factor values. Space between iso-erodents was coded according to the range of the predicted R-factor values. R-factor values for sites between iso-erodents may be predicted by linear interpolation.

The climatic data used in this study were obtained from various sources: articles, theses, and climatic reports as well as Honduran institutions, such as Empresa Nacional de Energía Eléctrica (ENEE), Departamento de Servicios Hidrologicos y Climatologicos de Honduras (DSHC), Servicio Meteorologico Nacional de Honduras (SMN), Servicio Nacional de Acueductos y Alcantarillas (SANAA), and many other agencies and institutions (see Mikhailova, 1995a,b for a complete compilation of climatic data and a reference list of data sources).

The basemap of Honduras used in this study is a $1: 1,000,000$-scale vector basemap obtained from the Digital Chart of the World, a comprehensive geographic information system (GIS) database for use with ARC/INFO ${ }^{\otimes}$ and ArCView software (Environmental Systems Research Institute, Inc., 1993) •

The regression approach for estimating $R$-factor values was used in conjunction with a GIS to compile the isoerodent map of Honduras. The Universal Soil Loss Equation 
1 (USLE) and the Revised Universal Soil Loss Equation (RUSLE)

2 have been interfaced with geographic information systems in

3 earlier studies (Spanner et al., 1982; Blaszczynski, 1992).

4

5

6

7

8

9

10

11

12

\section{RESULTS AND DISCUSSION}

\section{Predicting Rainfall Erosivity from Average Annual} Precipitation and Elevation

Inspection and statistical analysis of the data in Table 1 showed a positive linear relationship between rainfall erosivity index and average annual precipitation, and a negative linear relationship between rainfall erosivity and elevation (Fig. 1, Fig. 2, respectively).

A linear regression relationship was established estimating the rainfall erosivity index ( $R$ ) from the average annual precipitation and elevation:

$$
R_{i}=-699.3+7.0001 P_{i}-2.7190 E_{i}
$$

where $i$ denotes location $i=1,2,3 \ldots n$, at which $\mathbf{R}_{\mathbf{i}}=$ point estimate of $\mathrm{R}$-factor value;

$\mathbf{P}_{\mathbf{i}}=$ average annual precipitation in $\mathrm{mm} ;$ $\mathbf{E}_{\boldsymbol{i}}=$ elevation in meters. 
The coefficient of multiple determination $\left(R^{2}\right)$ for this regression equation is $0.972(p=0.000)$. Elevation was statistically significant, with a partial $t$-value of $-4.46(p=0.007)$. This data set did not have any multicollinearity problems (Neter et al., 1990, p.295), as indicated by the tolerance value of 0.959 . Statistical diagnostics did not reveal any deviations from the assumptions of the multiple regression model.

To the authors' knowledge, elevation has not been used previously for predicting the rainfall erosivity index. Studies in Costa Rica and Sri Lanka (Vahrson, 1990; Joshua, 1977) suggested an inverse relationship between rainfall erosivity and elevation. To examine the significance of elevation in estimating the rainfall erosivity index for other geographic areas, published data sets for Costa Rica (Vahrson, 1990; Instituto Meteorologico Nacional de Costa Rica, 1988), Sri Lanka (Joshua, 1977; Domroes and Ranatunge, 1993), and selected states from the southeastern United States (CITY Database of RUSLE, Version 1.03, 1993) were analyzed statistically. Table 2 presents the summary of predictive equations for the R-factor values for Honduras, Costa Rica, Sri Lanka, and the southeastern United States. In all four cases there is an inverse relationship between rainfall erosivity index $(R)$ and elevation, and the coefficient of multiple determination of each multiple regression model 
increased significantly when elevation was incorporated as a second predictor variable, after average annual precipitation.

A possible explanation for the inverse relationship between R-factor and elevation is as follows. R-factor is calculated from the kinetic energy of individual rainstorms. The kinetic energy of an individual storm is dependent on rainfall intensity, which is influenced by the median raindrop size and the terminal velocity of the freefalling raindrops. The median raindrop size generally increases with greater rain intensity (wischmeier and Smith, 1958) and the terminal velocities of free-falling water-drops increase with larger drop size (Gunn and Kinzer, 1949). According to Beard (1985), the altitude factor for adjusting raindrop velocities from sea level depends primarily on air density and drop size. Air density decreases by about seven percent for every $1,000 \mathrm{~m}$ (3,280 feet) of elevation, so the kinetic energy of falling raindrops should be greater at $1,000 \mathrm{~m}$ elevation than at sea level (MCIsaac, 1990). Conversely, at greater heights there are more small drops and very few large drops, because of the absence of pronounced accretion (Caton, 1966). Also, there is less raindrop coalescence at higher elevations because of decreased distance between the clouds and the ground. Therefore at higher elevations, the low concentration of large drops formed by accretion and 
1 coalescence causes a decrease in raindrop mass, which could

2 overcome the influence of decreased air density on velocity

3 and consequently could result in a net decrease in the

4 kinetic energy. This suggested hypothesis has not been

5 investigated by field studies.

6

Developing the Iso-erodent Map

Climatic stations of Honduras were plotted on the basemap of Honduras (Fig. 3, data layer 1) according to their geographic coordinates. To create the average annual precipitation data layer of Honduras (Fig. 3, data layer 2 ), an inverse distance weighted (IDW) interpolation routine within the GIS (ARC/INFO ${ }^{\otimes}$, version 6.1.2) was used to interpolate between station points and assign an average annual precipitation value to each 10 by $10 \mathrm{~km}$ grid-cell on the map. The elevation data layer (Fig. 3, data layer 3) was obtained from the Digital Chart of the World (Environmental Systems Research Institute, Inc, 1993). A data layer of the estimated R-factor value for each gridcell (Fig. 3, data layer 4) was generated using equation (2) with inputs from the average annual precipitation data layer and the elevation data layer.

A $95 \%$ prediction interval for the $R$-factor value at every location can be found in GIS from the general prediction interval formula (Neter et al., 1990, p.246). 
1 The estimated variance matrix of the regression coefficient

2 estimates is used to obtain the $95 \%$ prediction interval at

3 each new location, given by

4

$$
5 \quad R_{1} \pm 2.571\left\{\begin{array}{l}
\left.855014-935.847 \mathrm{P}_{1}-674.647 \mathrm{E}_{1}+\right]^{1 / 2} \\
0.390148 \mathrm{P}_{1}{ }^{2}+0.370995 \mathrm{E}_{1}{ }^{2}+ \\
0.153343 \mathrm{P}_{1} \mathrm{E}_{1}
\end{array}\right]
$$

6

7 where $i$ denotes location $i=1,2,3 \ldots n$, at which

$8 \quad \mathbf{R}_{\mathbf{i}}=$ point estimate of $\mathrm{R}$-factor value (equation (2));

$9 \quad \mathbf{P}_{\mathbf{i}}=$ average annual precipitation in $\mathrm{mm} ;$

$10 \quad \mathbf{E}_{\mathbf{i}}=$ elevation in meters.

Expressing the R-factor point estimate and $95 \%$ prediction interval in this algebraic form allows the estimation of the R-factor value and corresponding $95 \%$ prediction interval for each 10 by $10 \mathrm{~km}$ grid-cell in the GIS interface. Using equation (3), separate data layers were generated containing the upper (Fig. 3, data layer 5) and lower (Fig. 3, data layer 6) prediction limits for the R-factor estimate for each grid-cell. The lower prediction limit values were then subtracted from the upper values to obtain a third data layer containing the 958 prediction interval width for the R-factor estimate for each grid-cell (Fig. 3, data layer 7). These values were used to produce contour lines representing the width of the $95 \%$ prediction interval of the new R-factor estimates (Fig. 3, data layer 
8). These contour lines were then added to the iso-erodent map of Honduras.

\section{Provisional Iso-erodent Map of Honduras}

The iso-erodent map of Honduras is presented in Fig. 4. Different ranges of the estimated R-factor value are coded by color. The new R-factor estimate can be obtained from the map with its corresponding 95\% prediction interval. For example, the solid yellow region in southern Honduras represents the range of the estimated R-factor

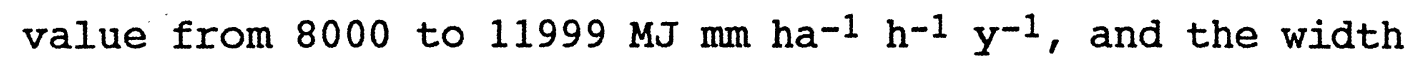
of the $95 \%$ prediction interval is $3000 \mathrm{MJ} \mathrm{mm} \mathrm{ha-1} \mathrm{h}^{-1} \mathrm{y}^{-1}$; therefore the $95 \%$ prediction interval for the R-factor

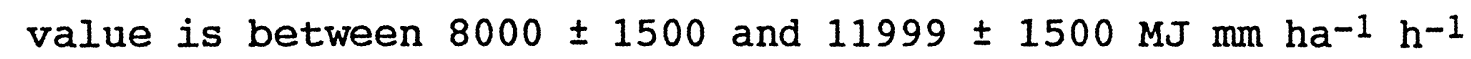
$\mathrm{y}^{-1}$. For any location of interest, both a point estimate and a prediction interval for the $\mathrm{R}$-factor value can be obtained from the digital provisional map of Honduras (Mikhailova, 1995b).

The lowest range of estimated $R$-factor value, from 0 to $3999 \mathrm{MJ} \mathrm{mm} \mathrm{ha-1} \mathrm{h}^{-1} \mathrm{y}^{-1}$, is found primarily near the capital of Honduras, Tegucigalpa. Estimated R-factor values for this central region of the country generally vary from 0 to $8000 \mathrm{MJ} \mathrm{mm} \mathrm{ha}^{-1} \mathrm{~h}^{-1} \mathrm{y}^{-1}$. The high range of estimated R-factor values, from 8000 to $16000 \mathrm{MJ} \mathrm{mm} \mathrm{ha-1} \mathrm{h}^{-1} \mathrm{y}^{-1}$, is found primarily in the 
1

coastal regions, as well as in the Lake Yojoa area, which is inland.

The Caribbean lowlands in northeastern Honduras are characterized by the highest range of estimated R-factor values, greater than $16000 \mathrm{MJ} \mathrm{mm} \mathrm{ha-1} \mathrm{h}^{-1} \mathrm{y}^{-1}$. This region also has the highest average annual precipitation (Perfil Ambiental de Honduras, 1989).

The contour lines representing the width of the $95 \%$ prediction interval for the R-factor value are shown in Fig. 4 in increments of 1000 R-factor units on the provisional iso-erodent map of Honduras. This approach allows for the identification of areas where the multiple regression model (2) used to predict R-factor values may not be appropriate. The best estimates of the R-factor values, with the narrowest prediction intervals, are found near the eight climatic stations with calculated R-factor values. Any station with average annual precipitation outside the range of 831 to $1313 \mathrm{~mm}$ or elevation outside the range of 360 to $1080 \mathrm{~m}$ has a wide prediction interval. Wide prediction intervals are associated with R-factor values for the stations in the Caribbean lowlands.

\section{Limitations of the Study}

The validity of using the rainfall erosivity index ( $R$ ) as a predictor of rainfall erosive power in Honduras has 
1 not been verified by field studies. The expense of setting

2 up and maintaining field equipment is one major reason why

3 this has not been done in the framework of this study. The

4 rainfall energy for the R-factor estimates (Zavgorodnaya de

5 Costales, 1990) used in this study were calculated from

6 equation ( 1 ), which is not the most current method for

7 estimating rainfall energy. Equation (1) has recently been

8 replaced by another relation (Brown and Foster, 1987):

9

10

11

$$
e_{x}=0.29\left[1-0.72 \exp \left(-0.05 i_{x}\right)\right]
$$

where

$\mathbf{e}_{\mathbf{x}} \quad=$ kinetic energy in megajoules per hectare per millimeter of rainfall (MJ ha-1 $\mathrm{mm}^{-1}$ );

$i_{r} \quad=$ intensity of rainfall $\left(\mathrm{mm} \mathrm{h}^{-1}\right)$.

Equation (4) is a better estimator of rainfall energy than equation (1) because it is based on more data than the relationship in equation (1) (Brown and Foster, 1987). Even though equation (1) was used in Honduras to estimate rainfall energy, comparison of the two relations (equation (1) and equation (4)) in the United States resulted in a difference of less than $1 \%$ in the EI (storm erosivity index) of sample storms (Renard et al., 1994). It was impossible to recalculate the rainfall energy per unit depth of rainfall using equation (4) for the eight stations 
1 used in this study, because the daily rainfall records were

2 not available. However, such recalculation could increase

3 the accuracy of this study.

4

R-factor values have been estimated from average

5 annual precipitation and elevation data obtained from many

6 different sources. Frequently, values of geographic

7 coordinates and elevation for the same station have varied

8 from one source to another. The most recent available

9 climatic data and geographic coordinates have been selected

10 for this study. If more accurate climatic information is

11 obtained in the future for any station, the estimated R-

12 factor value can be recalculated easily using equation (2).

13 The most accurate R-factor estimates are obtained for

14 the stations whose average annual precipitation and

15 elevation values fall in the joint region outlined by the

16 circle in Fig. 5. Because regression equation (2) is

17 obtained from observations all lying within this circle,

18 extrapolation is required for observations far outside this

19 circle. Therefore, regression equation (2) may not be

20 appropriate for estimating R-factor values for stations

21 whose average annual precipitation falls far outside the

22 range of 831 to $1313 \mathrm{~mm}$ or whose elevation falls far

23 outside the range of 360 to $1080 \mathrm{~m}$. Most of the stations

24 located in the coastal areas of Honduras are outside of

25 these ranges of average annual precipitation and elevation.

26 Furthermore, the eight stations with calculated R-factor 
values have similar monthly rainfall distributions (Fig. 6), so using equation (2) to estimate R-factor values may not be appropriate for those stations with different monthly rainfall distribution.

The eight stations with calculated $\mathrm{R}$-factor values are located in the El Cajon watershed area, which represents approximately $8 \%$ of the national territory of Honduras (Zavgorodnaya de Costales, 1990). Since the iso-erodent map of Honduras is based on only these eight calculated Rfactor values, it should be viewed as a preliminary study to evaluate rainfall erosivity. The small number of stations with calculated R-factor values and the density of climatic stations in Honduras did not allow the use of spatial statistics, such as kriging, to determine the accuracy of the estimated mean $\mathrm{R}$-factor values in different geographic areas of Honduras.

All statistical calculations in this study were performed using the Minitab ${ }^{\circledR}$ statistical software program (Ryan et al., 1994). It should be noted for further investigations that use of different computer regression packages may lead to slightly different numerical results, because of the numerical accuracy of the calculations (Neter et al., 1990, p.262). Finally, there is unknown error introduced by the interpolation in the GIS routines used to generate the various data layers and by the 
1 overlaying of data layers with different spatial

2 resolutions.

3

The limitations in the prediction of the rainfall

4 erosivity in Honduras by the method of this study should

5 not be discouraging for people who must make decisions on

6 land use in the country. The iso-erodent map presented in

7 this study represents the best available information for

8 Honduras. As pointed out by Van Wambeke (1987),

9 information with known limitations can lead to better

10 decisions, if used carefully, than those made without

11 information. 
REFERENCES

Babu, R., K.G. Tejwani, M.C. Agarwal and L.S. Bhushan. 1978. Distribution of erosion index and iso-erodent map of India. Indian J. Soil Conserv. 6(1):1-12. Beard, K.V. 1985. Simple altitude adjustments to raindrop velocities for Doppler radar analysis. J. of Atmospheric and Oceanic Technology 2:468-471.

Blaszczynski, J. 1992. Regional soil loss prediction utilizing the RUSLE/GIS interface. p. 122-131. In A.I. Johnson, C.B. Pettersson, and J.L. Fulton (ed.), Geographic Information Systems (GIS) and Mapping Practices and Standards. ASTM STP 1126. American Society for Testing and Materials, Philadelphia. Bollinne, A., A. Laurant, P. Rosseau, J.M. Pauwels, D. Gabriels and J. Aelterman. 1980. Provisional rain erosivity map of Belgium. In M. DeBoodt and D. Gabriels (ed.), Assessment of Erosion. John Wiley \& Sons, Chichester. p. 111-120.

Bonilla, R.M. 1991. Determinación de las tasas de erosion para la cuenca El Cajon y priorización de áreas de tratamiento ( $\mathrm{Vol} . \mathrm{II}$ ). Thesis. Universidad Nacional Autónoma de Honduras, Facultad de Ingeniería. Brown, L.C., and G.R. Foster. 1987. Storm erosivity using idealized intensity distributions. Trans. ASAE 30:379386 . 
1 Caton, P.G.F. 1966. A study of raindrop-size distributions in the free atmosphere. Quat. J. Royal Meteor. Soc. $92: 15-30$.

CITY Database of RUSLE, Version 1.03, 1993. Soil and water Conservation Society.

Domroes, M., and E. Ranatunge. 1993. A statistical approach towards a regionalization of daily rainfall in sri Lanka. International Journal of Climatology 13:741754 .

Environmental Systems Research Institute, Inc. 1993. Digital chart of the world for use with ARC/INFO ${ }^{\circledR}$ software.

Foster, G.R., D.K. MCCool, K.G. Renard, and w.C. Moldenhauer. 1981. Conversion of the Universal Soil Loss Equation to SI metric units. J. of Soil and water Conserv. $36(6): 355-359$.

Gunn, R., and G.D. Kinzer. 1949. Terminal velocity of fall for water droplets in stagnant air. J. of Meteor. $6(4): 243-248$.

Instituto Meteorologico Nacional de Costa Rica. 1988. Catastro de las series de precipitaciones medidas en Costa Rica. Ministerio de Recursos Naturales, Energía y Minas. Costa Rica, San Jose.

Joshua, W.D. 1977. Soil erosive power of rainfall in the different climatic zones of Sri Lanka. p 51-61. In Erosion and Solid Matter Transport in Inland Waters. 
IAHS-AISH Publication No. 122. Symposium, Paris, July 1977 .

Lal, R. 1990. Soil Erosion in the Tropics: Principles and Management. MCGraw-Hill, New York.

McIsaac, G.F. 1990. Apparent geographic and atmospheric influences on raindrop sizes and rainfall kinetic energy. J. Soil water Conserv. 45(6):663-666.

Mikhailova, E.A. 1995a. Predicting rainfall erosivity in Honduras. M.S. thesis. Dept. of Soil, Crop and Atmospheric Sciences, Cornell Univ., Ithaca, NY. Mikhailova, E.A. 1995b. Predicting rainfall erosivity in Honduras. Cornell International Institute for Food, Agriculture and Development (CIIFAD). Box 14 Kennedy Hall, Cornell University, Ithaca, NY 14853.

Neter, J., W. Wasserman, and M.H. Kutner. 1990. Applied Linear Statistical Models: Regression, Analysis of Variance, and Experimental Designs. 3rd ed. Richard D.Irwin, Inc., Homewood, IL.

Perfil Ambiental de Honduras. 1989. Secretaría de Planificacion , Coordinacion y Presupuesto (SECPLAN), Development Strategies for Fragile Lands (DESFIL). Funded by United States Agency for International Development.

Renard, K.G., and J.R. Freimund. 1994. Using monthly precipitation data to estimate the $R$-factor in the revised USLE. Journal of Hydrology 157:287-306. 
Renard, K.G., G.R. Foster, G.A. Weesies, and D.K. McCool, (Coordinators). 1994. Predicting soil erosion by water - a guide to conservation planning with the revised universal soil loss equation (RUSLE). Agriculture Handbook 703. US Govt. Printing Office, in press. Renard, K.G., G.R. Foster, G.A. Weesies, and J.P. Porter. 1991. RUSLE - revised universal soil loss equation. J. Soil water Conserv. 46(1):30-33.

Ryan, B.F. and B.I. Joiner. 1994. Minitab Handbook. 3rd ed. Duxbury Press, An Imprint of Wadsworth Publishing Company, Belmont, CA.

Spanner, M.A., A.H. Strahler, and J.E. Estes. 1982. Soil loss prediction in a Geographic Information System format. In Papers Selected for Presentation at the Sixteenth International Symposium on Remote Sensing of Environment. Vol. 1. 2-9 June 1982. Buenos Aires, Argentina.

Vahrson, W. 1990. El potencial erosivo de la lluvia en Costa Rica. Agronomía Costarricense $14(1): 15-24$. Van Wambeke, A. 1987. Soil moisture and temperature regimes of Central America, Caribbean, and Mexico. SMSS Technical Monograph \# 16, Soil Conservation Service, U.S.D.A., Washington, D.C. Wischmeier, W.H., and D.D. Smith. 1958. Rainfall energy and its relationship to soil loss. Trans. AGU 39:285-291. 
1 Wischmeier, W.H. and D.D. Smith. 1978. Predicting rainfall erosion losses - a guide to conservation planning. Agriculture Handbook No. 537, USDA, Washington.

Wischmeier, W.H. and D.D. Smith. 1965. Predicting rainfallerosion losses from cropland east of the Rocky Mountains - guide for selection of practices for soil and water conservation. Agriculture Handbook No. 282 . USDA, washington, DC. Zavgorodnaya de Costales, S. 1990. Trabajos Geomorfologicos Cuantitativos en la Cuenca El Cajon. Empresa Nacional de Energia Electrica, Tegucigalpa, Honduras. 
2

3 Table 1. Calculated erosivity index $\mathrm{R}$ for selected

climatic stations in the El Cajon watershed area (Zavgorodnaya de Costales, 1990; Bonilla, 1991).

6 Table 2. Summary of predictive equations for Honduras, Costa Rica, Sri Lanka, and Southeastern USA. 
Table 1. Calculated erosivity index $\mathrm{R}$ for selected climatic stations in the El Cajon watershed area (Zavgorodnaya de Costales, 1990; Bonilla, 1991).

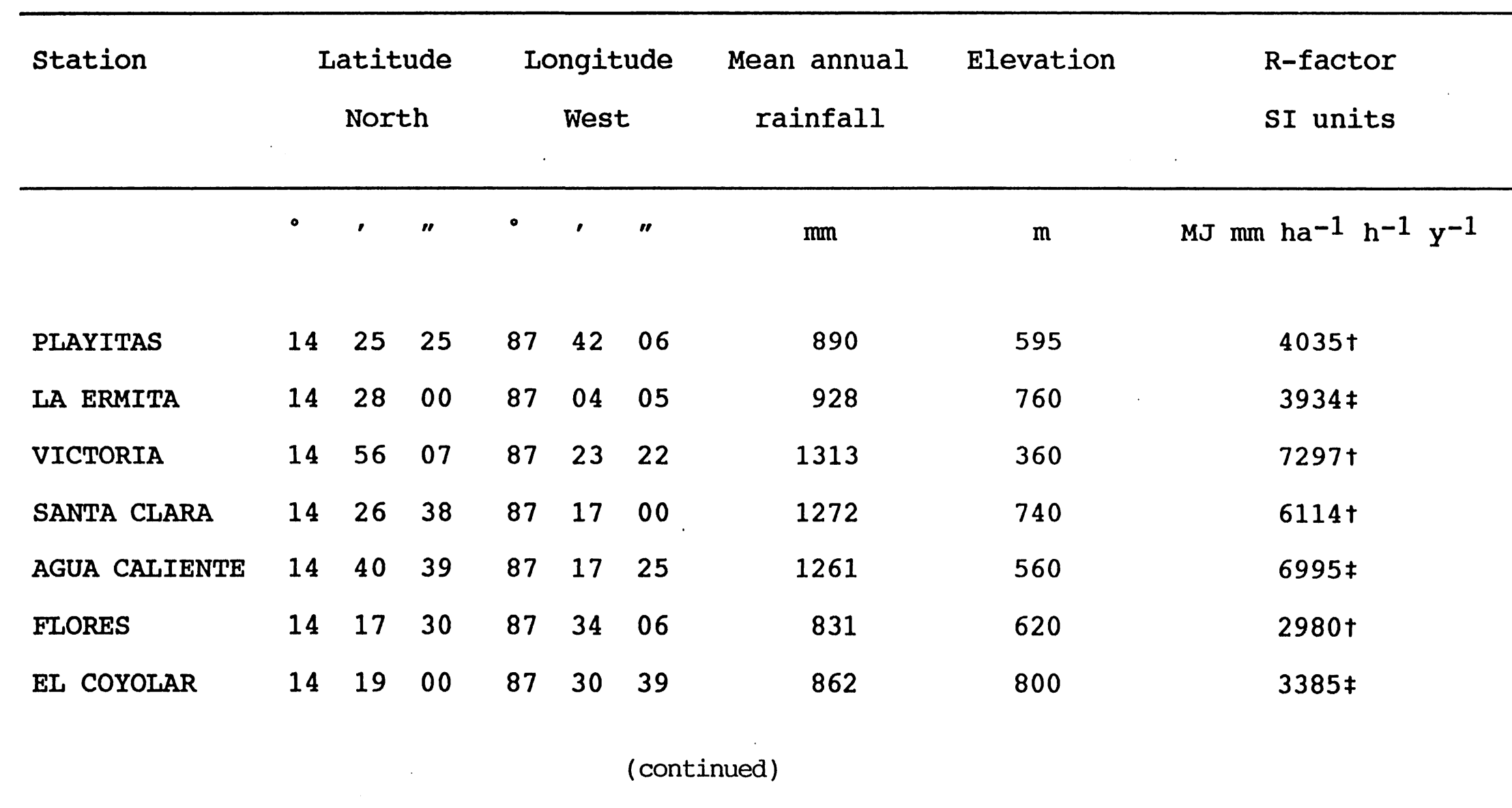




\section{$+\quad$ Average of 15 years.}

$\neq \quad$ Average of 16 years. 
Table 2. Summary of predictive equations for Honduras, Costa Rica, Sri Lanka, and Southeastern USA.

Equation

$n \quad d f^{\dagger} \quad M S E \quad R^{2 \neq} \quad p$-value

Bonduras

$\begin{array}{llllll}R=-3172.0+7.5620 \mathrm{P} & 8 & 6 & 460371 & 0.860 & 0.001 \\ \mathrm{R}=7696.0-4.0950 \mathrm{E} & 8 & 6 & 2411857 & 0.265 & 0.192 \\ \mathrm{R}=-699.3+7.0001 \mathrm{P}-2.7190 \mathrm{E} & 8 & 5 & 110808 & 0.972 & 0.000\end{array}$

Costa Rica

$\begin{array}{lrrrrr}R=2110.1+1.4743 \mathrm{P} & 111 & 109 & 6841829 & 0.330 & 0.000 \\ \mathrm{R}=8449.9-1.8263 \mathrm{E} & 111 & 109 & 7729583 & 0.243 & 0.000 \\ \mathrm{R}=3786.6+1.5679 \mathrm{P}-1.9809 \mathrm{E} & 111 & 108 & 3979794 & 0.614 & 0.000\end{array}$

Sri Lanka

$\begin{array}{lllrll}R=-727.0+3.7711 \mathrm{P} & 8 & 6 & 2081153 & 0.857 & 0.001 \\ R=6063.0-3.9850 \mathrm{E} & 8 & 6 & 13602653 & 0.067 & 0.535 \\ R=-344.1+3.8473 \mathrm{P}-4.8460 \mathrm{E} & 8 & 5 & 764276 & 0.956 & 0.000\end{array}$

(continued) 
Southeastern USA

\begin{tabular}{llllll}
$R=-9100.0+11.8500 \mathrm{P}$ & 24 & 22 & 3346952 & 0.497 & 0.000 \\
$R=6891.0-2.8793 \mathrm{E}$ & 24 & 22 & 4457593 & 0.330 & 0.003 \\
$R=-5704.0+9.7580 \mathrm{P}-1.9475 \mathrm{E}$ & 24 & 21 & 2562077 & 0.632 & 0.000 \\
\hline
\end{tabular}

+ Degrees of freedom (df) associated with Mean Square Error (MSE) .

\# Coefficient of (multiple) determination.

$R$ R-factor estimate in SI units: $M \mathrm{~J}^{\prime} \mathrm{ma} \mathrm{a}^{-1} \mathrm{~h}^{-1} \mathrm{y}^{-1}$.

P Average annual precipitation in mm.

E Elevation in meters. 
2

3 Fig. 1 .

4

5

6 Fig. 2.

7

8

9 Fig. 3 .

10

11 Fig. 4 .

12

13 Fig. 5 .

14

15

16 Fig. 6.

\section{FIGURE CAPTIONS}

The relationship between calculated R-factor (R)

and average annual precipitation (P) at eight climatic stations in Honduras.

The relationship between calculated R-factor (R) and elevation (E) at eight climatic stations in Honduras .

Schematic representation of the approach used to produce provisional iso-erodent map of Honduras. Provisional iso-erodent map of Honduras (modified from Mikhailova, 1995a,b).

Plot of elevation against average annual precipitation for stations with calculated and estimated $\mathrm{R}$-factor values. Average monthly rainfall distribution for eight stations with calculated R-factor values. 


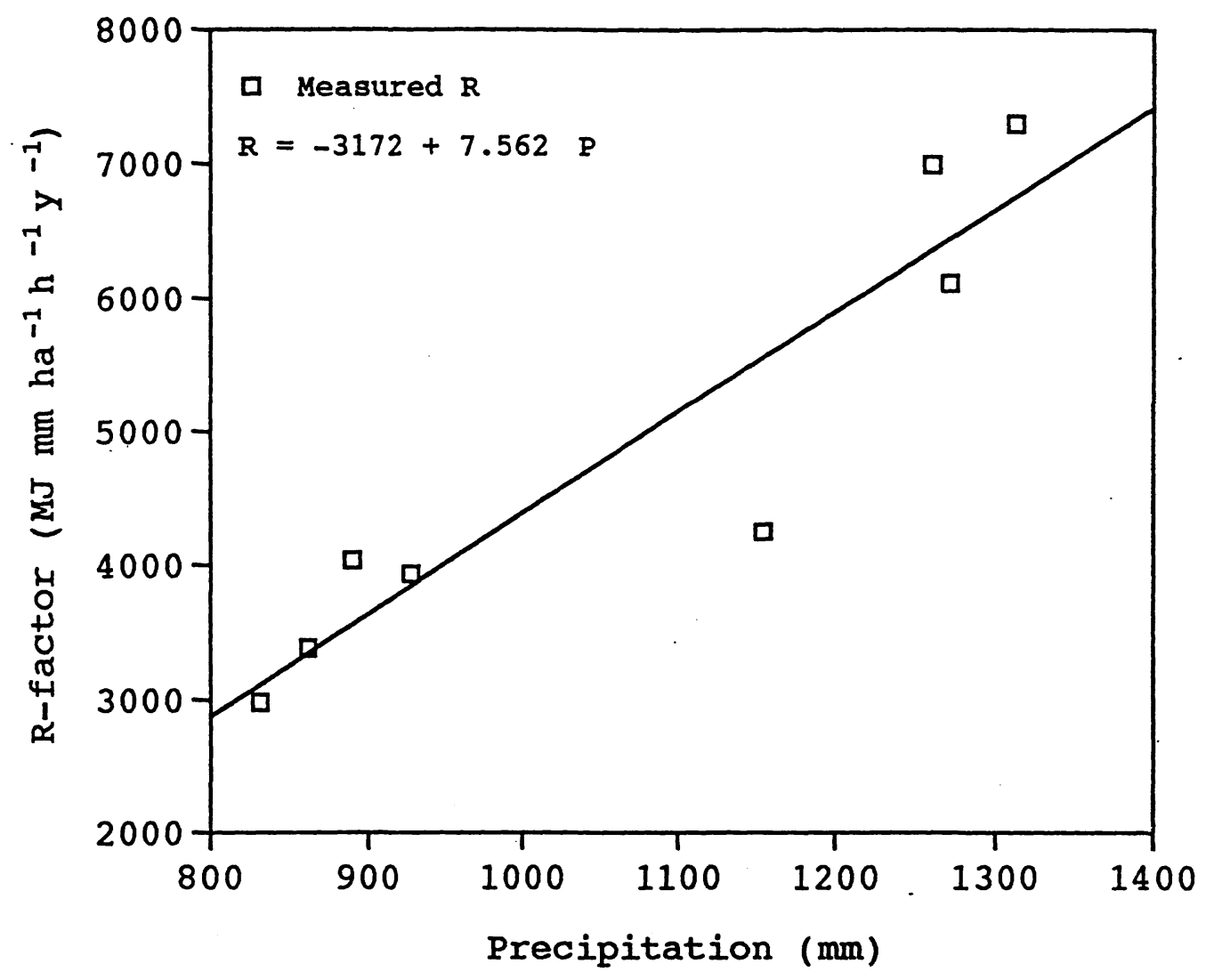

Fig. 1 


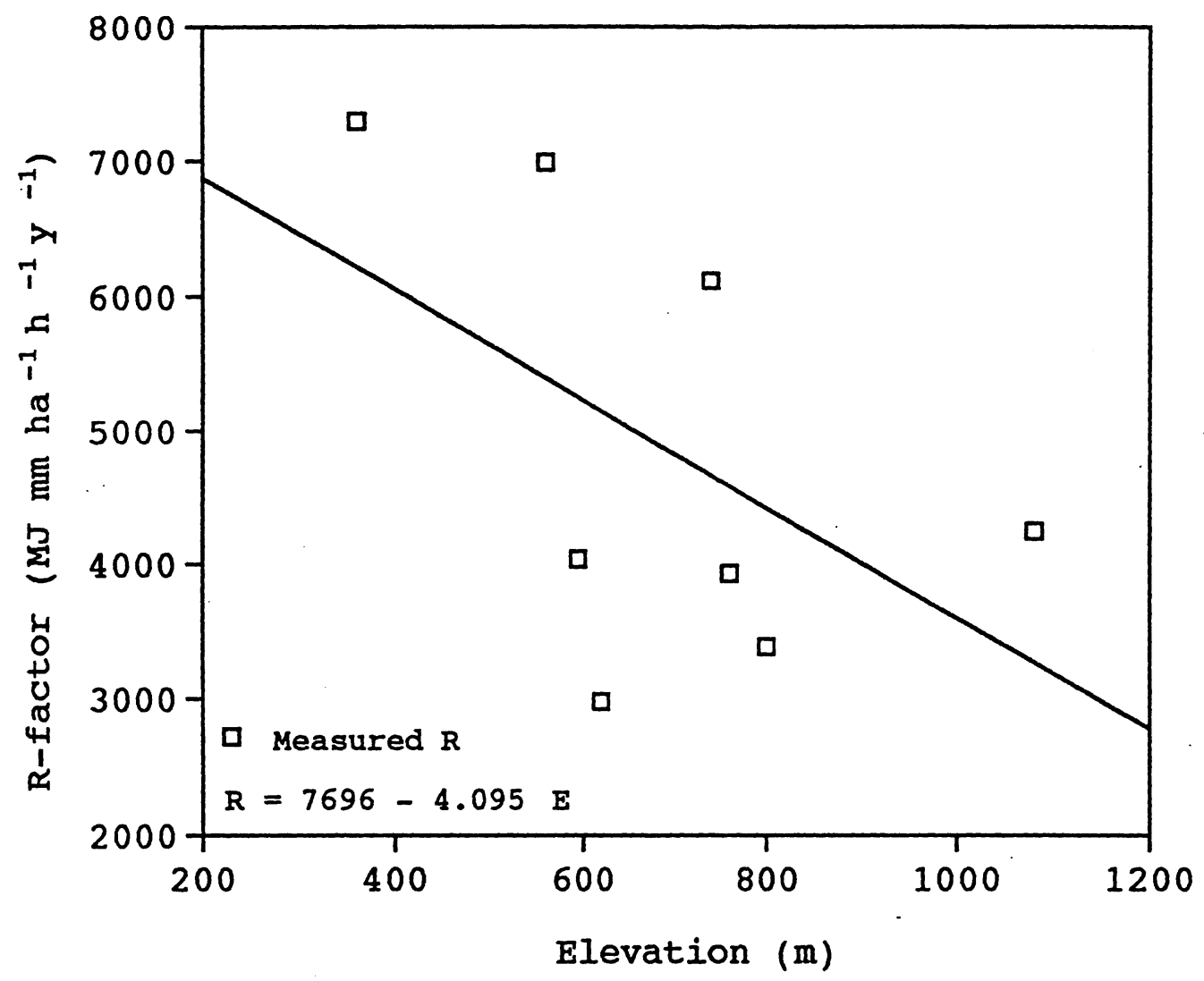

Fig. 2 


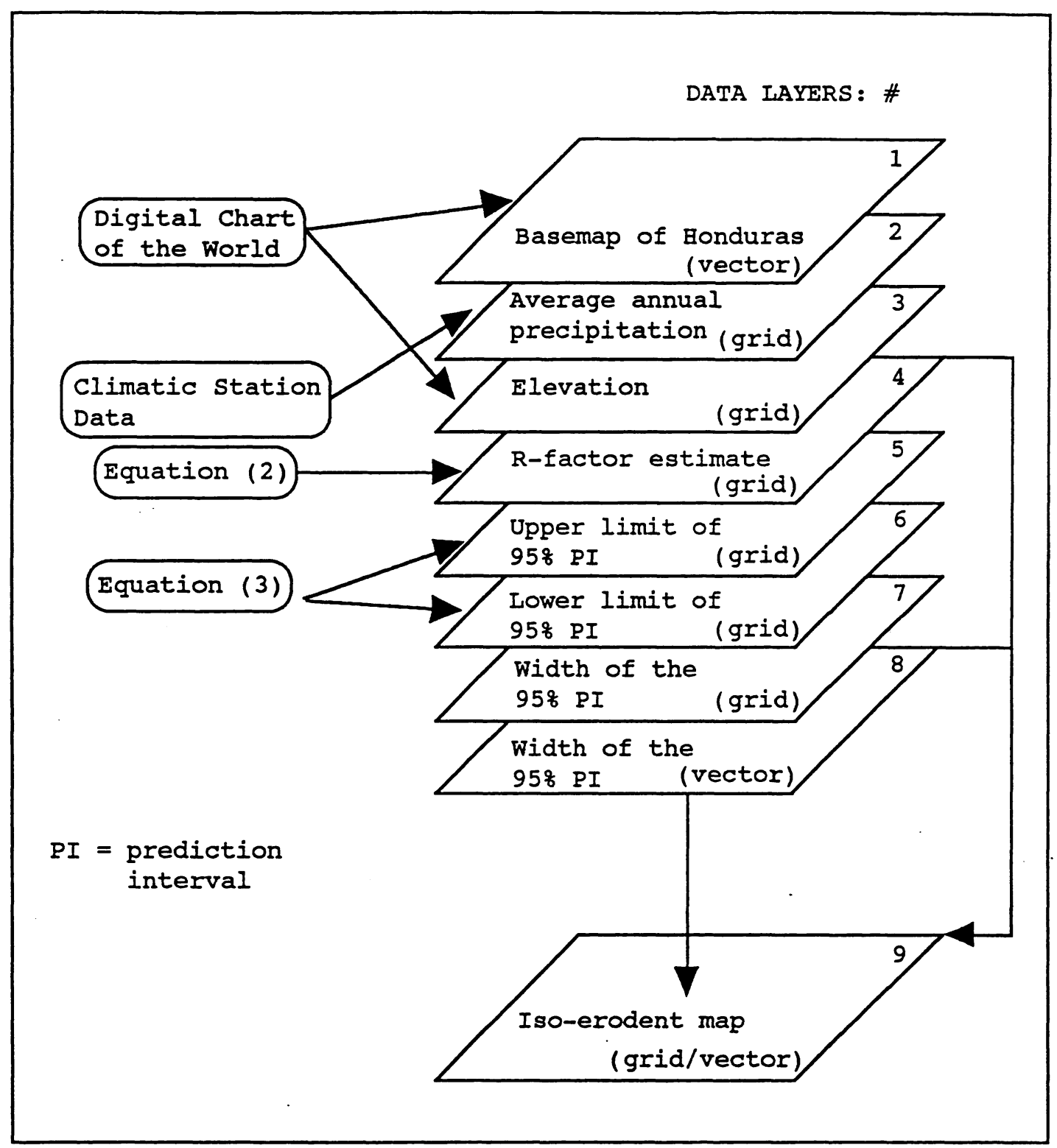

Fig. 3 


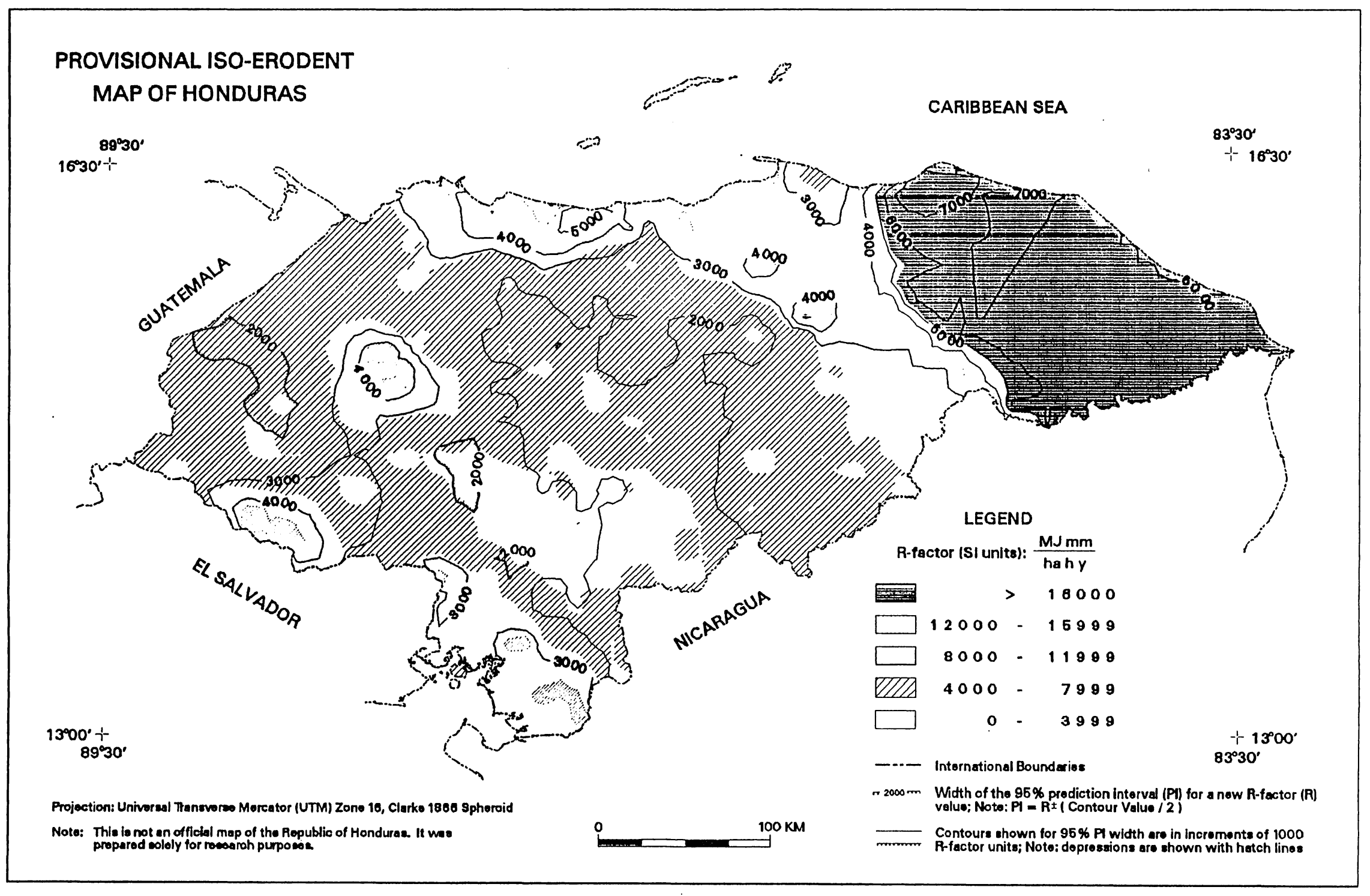

Fig. 4 


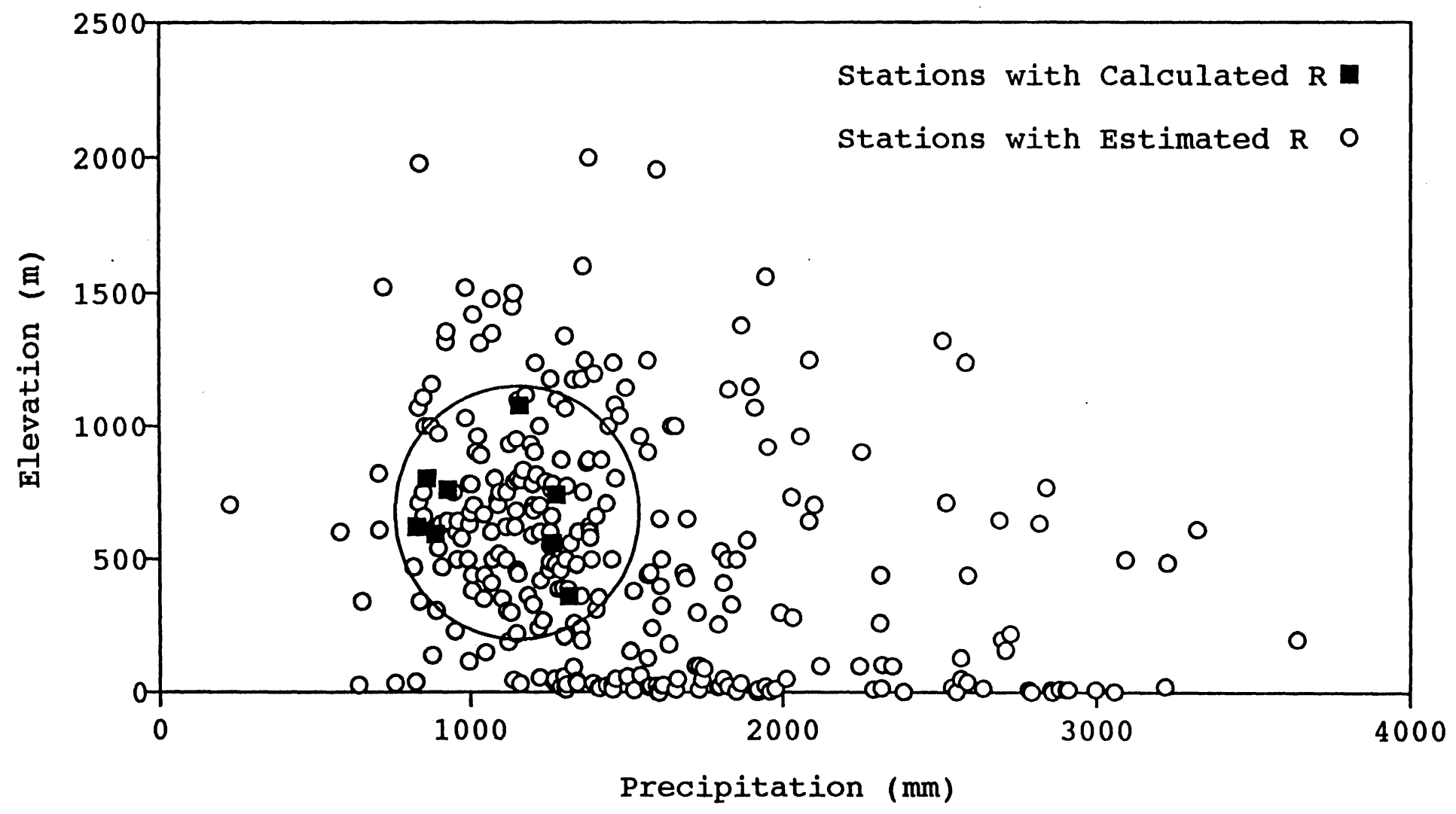

Fig. 5 


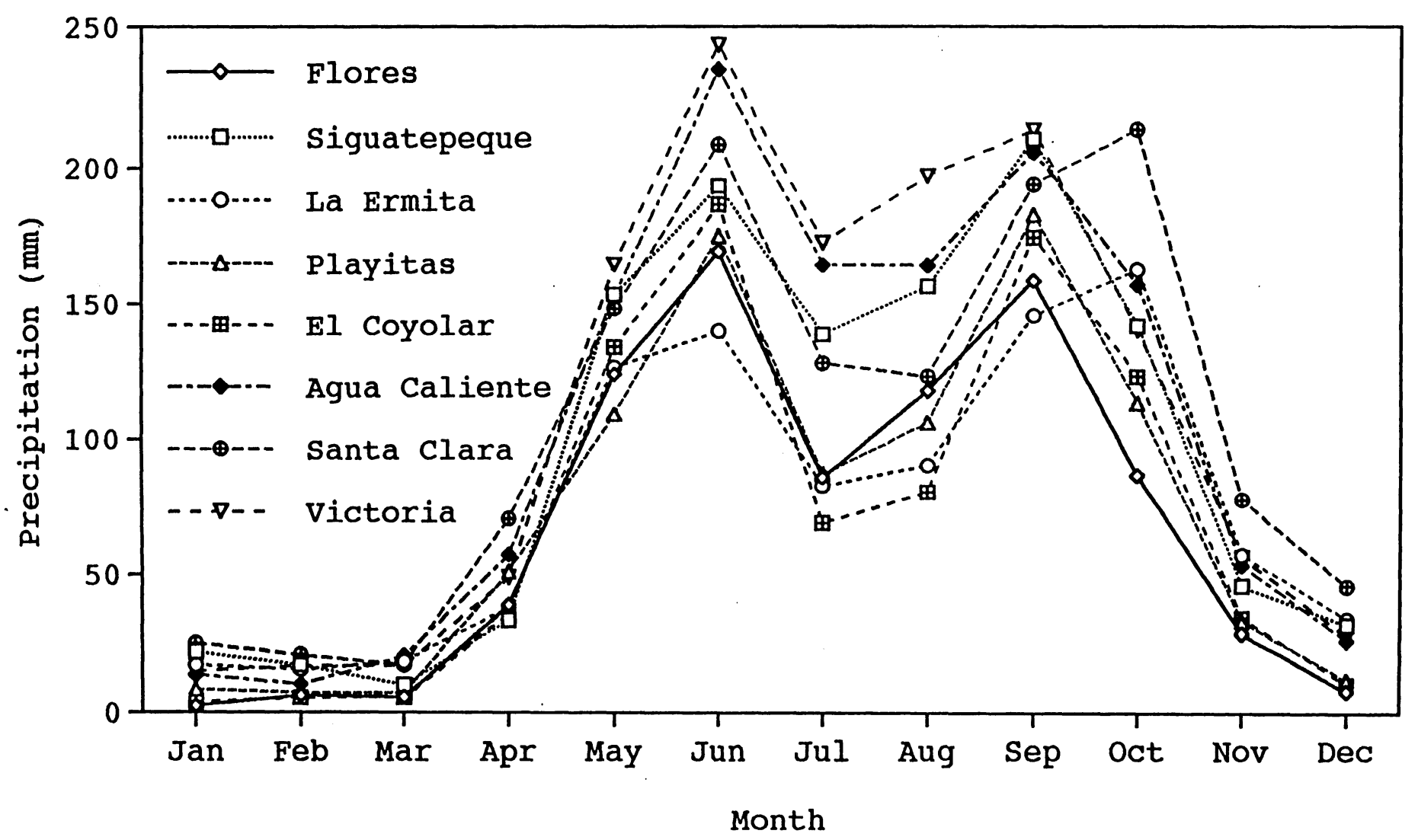

Fig. 6 